\title{
Production Efficiency of Fish Farming in Ibadan-Ibarapa Zone of Oyo State, Nigeria.
}

\author{
Sanusi W.A, Akinniran T.N, Akinyemi M.*, Ige, D.A \\ The Department Of Agricultural Economics, Ladoke Akintola ,University Of Technology, \\ Ogbomoso, Oyo State. \\ *Federal University, Dutsi-Maa, Katsina State
}

\begin{abstract}
This study investigates fish farming productivity by estimating the level of technical efficiency for a sample of fish farmers in Ido and Oluyole local government. Data was obtained from the respondents through a well structured questionnaires and interview schedule.

In this study, a total of 60 fish farmers were selected using multistage sampling techniques. Descriptive statistical tools were used to analyze the socio economic characteristics of the farmers and constraints facing them. Gross margin analysis was used to analyze costs and return. DEA analysis was used to determine their efficiency, while tobit regression model was used to analyse determinants of efficiency.

The study revealed that about $68.3 \%$ chose fish farming as their minor occupation, $63.3 \%$ engaged in fish farming for family consumption, $86.7 \%$ did it for sales. $70 \%$ have 1-5 years of fish farming experience, $66.67 \%$ have 1-10 years of farming experience, 75\% operated only 1 pond each. $40 \%$ of the respondents acquire their land through inheritance, $46.7 \%$ used earthen pond, $76.7 \%$ are members of cooperative society and $66.7 \%$ had no access to credit.

The finding shows that fish farming was profitable with net farm income of $\$ 374100.09$ per fish farmers in the study area. Majority of the fish farmers are relatively technical efficient in their use of resources with mean technical efficiency of $84.9 \%, 89.0 \%, 95.5 \%$, under CRS, VRS, and SE respectively. Farmers' sex and fish farming experience had inverse relationship with the efficiency of fish farming in the study areas, farmers' age had direct relationship under both CRS and VRS, while access to credit had direct relationship with efficiency under SE specification. The analysis shows a slack of $4.184 \mathrm{~kg}, 2,972.091 \mathrm{~m}^{2}, 2,411.008 \mathrm{~kg}, \$ 112,119.49$ and 2,284.597; in fish output, pond size, feed, labour and number of fingerlings respectively. Major problem facing the fish farmers were limited access to credit, marketing, transportation and access to quality feed.
\end{abstract}

The study therefore concluded that measures should be taken to improve technical efficiency, in order to bridge the gap between fish demand and supply, to bring about self sufficiency in fish production.

Keywords: Production, Efficiency and Fish Farming.

\section{BACKGROUND OF THE STUDY}

Fish existence is as old as human existence. Fishes have been consumed as food since the Paleolithic era, as a source of animal protein. The first appearance of fish on earth was recorded one million years ago. Fish naturally lives in water bodies e.g. river, ocean, and they can also be reared. Fish farming is the raising of fish for personal use or profit, with the aim of better use of land, water, source of food, income and employment to humans.

Nigeria fishing industry comprises of 3 major subsectors namely; the artisanal, industrial and aquaculture. The awareness on the potential of aquaculture to contribute to domestic fish production has continued to increase in the country. This stems from the need to meet the much needed fish for domestic production and export. Fish species which are commonly cultured include Tilapia spp ,Heterobranchusniloticus, Clariasgariepinus, Mugiespp, Chrisichthysnigrodigitatus ,Hetero nitoticus, Ophiocephalus obscure, Cypinuscarpio and Megalo spp. Fish culture is done in enclosures such as tanks. The aquaculture subsector, contributes between $0.5 \%$ and $1 \%$ to Nigeria domestic fish production (Adewuyi et al., 2010). 
Statistics indicated that Nigeria is the largest African aquaculture producer, with production output of over 15,489 tons per annum, this is closely followed by Egypt with output of about 5,645 tons. Only five other countries: Zambia, Madagascar, Togo, Kenya and Sudan: produce more than 1000 tons each. However Nigeria is among the largest fish consumers in the world, with over 1.5 million tons of fish, consumed annually. Yet today Nigeria has a big hole in her pocket, as the country imports over 900,000 metric tons of fish, while its domestic fish catch is estimated at 450,000 metric tons per year.

The large dependence on imported fish, has adversely affected her economy; and mostly foreign reserves (Davies et al 2008). Moreover the rapid increase in population of the world has resulted in a huge increase in demand, for animal protein. To solve the country's high demand for fish, Nigeria must turn to maximize the available resources (e.g. inland waters) and minimize constraints, including lack of seed and quality of feed. The challenge the efficiency on food production level in Nigeria appears to be more urgent now, than it has ever been in the history of the country. However, agricultural (food) problem needs much more concentration, because of its paramount importance. Apart from satisfying the inhabitants, it could also serve as source of income generation (tax), through marketing to other parts of the country and beyond (exports). The generated income could be used to solve other problems, mentioned aforetime. Moreover hunger and malnutrition remain amongst the most devastating problems facing the world poor and needy (FAO, 2002). About 80 to 90 million people have to be fed yearly and most of them are in developing countries. The most reliable source of protein for many is fish, yet millions of people who depend on fish are faced with the fear of food shortage (World Fish Centre, 2003).

With the population on the rise, there is a corresponding increase in the demand for fish consumption. To reduce the alarming increase in price of fish, there is a need for a suitable agricultural system, to meet the increasing demand for food. Also maximum utilization of the available limited resources is needed for this purpose. This is to increase supply, also to considerably reduce the price of fish, making it available to the masses, thus reducing malnutrition.

It is against this background that this study, intends to provide the answers to the following research questions:

1. What are the factors affecting the interest of farmers in fish farming?

2. What are the cost and returns to fish farming?

3. Are the fish farmers technically efficient?

4. What are the constraints to fish production in study area?

The general objective is to determine the technical efficiency and the profitability of fish farming in Ido and Oluyole local government, Ibadan.

The specific objectives include:

i. To estimate cost and return analysis of fish farming.

ii. To estimate technical efficiency of fish farmers in the study area

iii. To analyze factors affecting production efficiency of fish farming.

iv. To identify the constraint to fish production in study area.

\section{HYPOTHESES OF THE STUDY}

The hypothesis of the study are in null form

1. There is no significant relationship between the socio-economic characteristics of fish farmers and their production efficiency.

\section{METHODOLOGY}

\section{Study Area}

The study was carried out in Ido and Oluyole local government areas of Oyo state, Nigeria. The cardinal location of Ido local government is extremely within the tropics and bounded in the east by Akinyele, west by Ibarapa east local government, north by Ibadan south west and south by Egbeda 
local government. It has ten political wards with a land area of $1,010,950 \mathrm{~km}^{2}$. The annual rainfall is 1,480mm with peak from April to June, a July break and second peak from August to October. Agriculture is their predominant occupation of the people in Ido local government, though maingly cash crops and arable crops. They practice fisheries to an extent.

Oluyole local government is located in the tropic zone, lying between latitude $3^{0} \mathrm{E}$ and $5^{0} \mathrm{E}$ of the Greenwich meridian and between longitude $7^{0} \mathrm{~N}$ and $2^{0} \mathrm{~N}$ of the equator. It has the vegetation that is dominated with tropical rainforest region, due to its location in the southern part of the state. Oluyole local government area has annual rainfall of $1000-1400 \mathrm{~mm}$. They practice agriculture, predominated cash crops like cassava, Maize, Mango, Oil palm, Cocoa. Feed mills including fish feed mills could be seen as indication of aquaculture practice, as you travel along the area. It shares boundary with Ibadan southwest and east local government area, to the north, Ido local government area, to the northwest and Onaara local government area to the east. It also shares boundary with Ogun state, to the south.

It covers a land area of $629 \mathrm{~km}^{2}$ and a population of 202,725 from 2006 population census. The residents are Yoruba and other tribes of Christianity, Islamic, and traditional religious backgrounds. It also has a well functioning Fadama program.

\section{Population, Sampling Procedure and Sampling Size}

The population of the study includes all registered fish farmers of Fadama in Ido and Oluyole local government area of Oyo state.

Multistage random sampling was used. The two local government were purposively chosen because of higher concentration of fish farmers. 66.7\% (40) respondents were randomly selected from Oluyole local government and $33.33 \%$ (20) were chosen from Ido local government making a total of 60 fish farmers. This is due to comparatively higher concentration of fish farmers in Ido local government.

\section{METHOD OF DATA ANALYSIS}

Data was analyzed using descriptive statistics, Data Envelopment Analysis (DEA software) and Tobit regression model.

\section{i. Descriptive statistics analysis}

This entails the use of mean, frequency and percentages, Budgetary analysis was used to analyze profitability of fish farming in the area.

\section{ii. Data Envelopment Analysis (DEA software) and Tobit regression model}

DEA is a linear programming based technique for measuring the relative performance of Decision Making Units (DMUs) where the presence of multiple inputs and outputs make comparisons difficult. DEA is a relatively new approach for evaluating the performance of set of Decision Making Units (DMUs), which convert multiple outputs. The definition of DMUs is generic and in recent years has been a great variety of applications of DEA in evaluating the performance of many different kind engaged in different activities in many countries.DEA provide a means of calculating apparent efficiency levels within a group of DMUs. The efficiency of a DMU is calculated relative to the group's observed best practices (Ajao 2011).

It is used to determine the efficiency indices of the area. The models here will focus on the technical aspect of production.

$$
\begin{aligned}
& \mathrm{U}_{1} \mathrm{Y}_{1} \\
& \mathrm{~V}_{1} \mathrm{X}_{1} .
\end{aligned}
$$

Is obtained where $\mathrm{U}_{1}$ is a $\mathrm{Q}_{\mathrm{X} 1}$ vector of output weight and $\mathrm{V}$ is a $\mathrm{P}_{\mathrm{X} 1}$ vector input weight. The optimal weights are obtained by solving

$$
\begin{aligned}
& \mathrm{TE}_{\mathrm{CRS}}=\operatorname{Min} \theta \lambda \theta \\
& -\mathrm{Y}_{\mathrm{i}}+\mathrm{Y} \lambda \geq 0 \\
& -\lambda_{\mathrm{X} 1}+\mathrm{X} \lambda \geq 0
\end{aligned}
$$


Where $\theta$ is the scalar and $\lambda$ is $\mathbf{N}_{\mathbf{X} \mathbf{i}}$ vector of constant. The value $\theta$ will be efficiency score for the respondents. It will satisfy $\theta \leq 1$, with a value of 1indicating point on the frontier, hence technical efficiency according to Farrell (1957) definition. Value of less than indicates technique inefficiency.

Equation (1) can be modified VRS assumption as the permits calculation of technical efficiency devoid of scale efficiency (SE) effect.

$$
\begin{aligned}
& \mathrm{TE}_{\mathrm{VRS}}=\operatorname{Min} \theta \lambda \theta \\
& -\mathrm{y}_{\mathrm{i}}+\mathrm{y} \lambda \geq 0 \\
& -\theta_{\mathrm{X} 1}+\mathrm{x} \lambda=0 .
\end{aligned}
$$

\section{$\mathbf{N} 1^{*} \lambda \leq 1$}

$$
\lambda \mathbf{r} \geq 0
$$

Where $\mathbf{N}_{\mathbf{i}}$ is an $\mathbf{N}_{\mathrm{Xi}}$ vector of ones. A remaining aspect of DEA is that of scale efficiency (SE) which is a measure of whether or not, a producing unit is operating at an optimal scale of operation. To obtain SE, technical efficiency $\mathbf{T E}_{\mathrm{CRS}}$ will be decomposed into pure technical and scale inefficiency. If there is difference between the $\mathbf{T E}_{\mathrm{CRS}}$ and $\mathbf{T E}_{\mathrm{VRS}}$ score for a particular respondent, this indicates there is scale inefficiency. According to Sharma et al. (1998), VRS is more flexible and envelope the data in a more tightly way than CRS analysis. The $\mathbf{T E}_{\mathrm{CRS}}$ measures ( $\theta_{1}$ VRS) is equal to or greater than $\mathrm{TE}_{\mathrm{CRS}}$ measure $\left(\theta_{1} \mathrm{CRS}\right)$. This relationship is used to obtain a measure of scale efficiency (SE) of the respondent.

$$
\mathrm{SE}_{i}=\frac{\theta_{\text {crs }}}{\theta_{\text {vrs }}}
$$

Where $\mathrm{SE}=1$ indicates scale inefficiency or CRS and $\mathrm{SE}<1$ indicates inefficiency. Eqn (2) did not indicate whether the firm is operating on the increasing or decreasing return to scale. The measure did not indicate whether or not scale inefficiency occur because a production activity is operating at too large or too small a scale, only requires solving another DEA problem, the non-increasing return to scale (NIRS) model. $\mathrm{N} \uparrow \lambda=1$ restriction in (2) will be replaced by $\mathrm{NI}^{1} \lambda<1$ to have non increasing return to $\mathbf{T E}_{\text {nis }}=$ Min .

$$
\begin{aligned}
& \mathrm{TE}_{\mathrm{VRS}}=\operatorname{Min} \theta \lambda \theta \\
& \mathbf{y}_{\mathrm{i}}+\mathrm{v} \lambda \geq \mathrm{y} \lambda \\
& \theta_{\mathrm{X} 1}+\mathrm{x} \lambda \geq 0 \\
& \mathrm{NI}^{1} \lambda=1
\end{aligned}
$$

\section{$\lambda \geq 0$}

If the $\mathrm{TE}_{\mathrm{VRS}}=\mathrm{TE}_{\mathrm{n1rs}}$ denotes decreasing return to scale, if the $\mathrm{TE}_{\mathrm{VRS}} \neq \mathrm{TE}_{\mathrm{nirs}}$ denotes increasing return to scale.

Ii (b) Determinants of Efficiency

Tobit regression Model

This was used to analyze the determinants of efficiencies among fish farmers. The model can be stated as

$$
\begin{aligned}
& \mathbf{y}^{*}=\beta z+\mathrm{e} \\
& \mathbf{y}=\mathbf{y}^{*}(\beta z+\mathrm{e}) \text { ify } *>0 \\
& \mathbf{y}=0 \text { if } \mathbf{y}^{*} \leq 0 \\
& \mathbf{y}=\text { efficiency scores }
\end{aligned}
$$


$\mathrm{Z}=\mathrm{a}$ vector of explanatory variables

$\beta=$ vector of unknown variables

$\mathrm{e}=$ independently and normally distributed random error terms

$\mathrm{Z}_{1}=$ Age of the farmer (years)

$\mathrm{Z}_{2}=$ Gender $(1=$ male, $2=$ female $)$

$\mathrm{Z}_{3}=$ Years of schooling (years)

$\mathrm{Z}_{4}=$ Farm experience $($ years $) 7$

$\mathrm{Z}_{5}=$ Membership of cooperative society (yes $=1,0=$ otherwise)

$\mathrm{Z}_{6}=$ Access to credit (yes $=1,0=$ otherwise)

$\mathrm{Z}_{7}=$ Fish farming experience (Years)

$\mathrm{Z}_{8}=$ Household size (number)

\section{RESULT AND DISCUSSIONS}

\section{Cost and Returns of fish farming}

Cost is the expenditure that is involved in the production system while on the other hand, returns are referred to as the revenue generated on fish farming. The total cost (TC) and the total return can also be expressed in terms of their average cost and average return respectively. The total cost was divided into 2, namely: fixed cost and variable cost. Fixed costs are expenditure that do not vary as output changes while variable cost are expenditure incurred in production and vary as output changes.

\section{Analysis of Variable Cost}

Variable costs are costs which vary with output, that is, as output increases, cost of variable factor rises. Variable cost item in fish farming include labour, fingerlings and feed. From table 1, the average variable cost of fish farming was 164 468.34. Labour and feed accounted for $32.54 \%$ and $45.05 \%$, while fingerlings accounted for $22.41 \%$. This means that labour, fingerlings and feed are necessary in fish farming.

Table 1. Analysis of variable cost

\begin{tabular}{|l|l|l|}
\hline Item & Cost ( $)$ & Percentage (\%) \\
\hline Labour & 53526.67 & 32.54 \\
\hline Feed & 74086.67 & 45.05 \\
\hline Fingerlings & 36855.00 & 22.41 \\
\hline Total & 164468.34 & 100 \\
\hline
\end{tabular}

\section{Source: Field survey 2014}

\section{Analysis of Fixed Cost}

The fixed cost incurred by the farmers includes depreciated cost of land purchase and cost of pond construction, was estimated to be $\$ 62983.34$.

Table 2. Fixed cost

\begin{tabular}{|l|l|l|}
\hline Item & Cost ( $)$ & Percentage (\%) \\
\hline Land and pond construction & $62983.34(\mathrm{dep})$ & 100 \\
\hline
\end{tabular}

\section{Source: Field survey 2014}

\section{Analysis of Total Cost}

Total cost is the sum of the fixed and variable cost. Table 2 shows that fixed cost is the lowest, which account for $27.69 \%$ of the total cost of fish farming in the study area, while variable cost account for the remaining $72.31 \%$. This shows that variable cost is the most significant in fish production, in the study area. 
Sanusi W.A et al.

Table 2. Analysis of total cost

\begin{tabular}{|l|l|l|}
\hline Item & Cost $(\mathbf{N})$ & Percentage (\%) \\
\hline Fixed cost & 62983.34 & 27.69 \\
\hline Variable cost & 164468.34 & 72.31 \\
\hline Total cost & 227451.68 & 100 \\
\hline
\end{tabular}

\section{Source: Field survey 2014}

\section{Gross Margin and Net Income Analysis}

Table 3 shows the gross margin and net income analysis of fish farming in the study area. The total average revenue from fish farming was $\$ 549858.00$ with average variable cost of $\$ 164468.34$, which gives a gross margin of $\$ 385389.66$. The average fixed cost was $\$ 62983.34$ while the net farm income was $\$ 374100.09$. Benefit cost ratio was 2.4. This implies that fish farming in the study area, was a profitable enterprise.

Table 3. Gross margin and net farm income analysis

\begin{tabular}{|c|c|}
\hline Item & Value ( $¥$ \\
\hline Total revenue & 549858.00 \\
\hline Average variable cost & 164468.34 \\
\hline Gross margin & 385389.66 \\
\hline Average fixed cost & 62983.34 \\
\hline Net farm income & 374100.09 \\
\hline Benefit cost ratio & 2.4 \\
\hline
\end{tabular}

\section{Source: Field survey 2014}

\section{Production Efficiency Index of Fish Farmers}

Table 4 revealed the frequency distribution of fish farmers' economic efficiency under constant return to scale (CRS), variable return to scale (VRS) and scale efficiency (SE) estimates.

The mean technical efficiencies are $0.849,0.890,0.955$ for constant return to scale, variable return to scale and scale efficiency respectively. Substantial inefficiencies occurred in fish farming in the study area. Under the current circumstances, about $21.67 \%, 46.67 \%$, and $25 \%$ were identified as fully economically efficient under CRS, VRS, and SE specification respectively. The observed differences between CRS, VRS, and SE measures indicated that some of the fish farmers do not operate at an efficient scale and improvement in the overall efficiency could be achieved, if the farmers adjusted their scales of operation. Under CRS, the group with the highest frequency of technical efficiency is 0.9-0.999 amounting to $35 \%$ of the sampled fish farmers. This was followed by group 1.0 with a percentage of $21.67 \%$ of the total respondents. Under VRS, the group with highest frequency of production efficiency is 1.0 amounting to $46.67 \%$ of the sampled fish farmers, followed by $0.9-0.999$ with a percentage of $23.33 \%$. The lowest production efficiency falls within 0.2-0.299 group. Under scale efficiency, the group with highest is $0.9-0.999$ amounting to $60 \%$ of the sampled fish farmers, followed by group 1.0 amounting to $25 \%$ of the total respondent. The lowest frequency of production efficiency falls within 0.6-0.699 under scale efficiency. The minimum, maximum, standard deviation, mean of the distribution under CRS and VRS and scale efficiency are 0.283, 1.0, 0.2108,0.849 and $0.294,1.0,0.1860,0.890$ and $0.626,1.0,0.0698,0.955$ respectively.

Table 4. Frequency distributions of technical efficiency scores obtained with DEA model.

\begin{tabular}{|l|l|l|l|}
\hline Economic efficiency & Constant return to scale & Variable return to scale & Scale efficiency \\
\hline Frequency & Frequency & Frequency & Frequency \\
\hline $0.1-0.199$ & - & - & - \\
\hline $0.2-0.299$ & $1(1.67)$ & $1(1.67)$ & - \\
\hline $0.3-0.399$ & $3(5)$ & $2(3.33)$ & - \\
\hline $0.4-0.499$ & $1(1.67)$ & $2(3.33)$ & - \\
\hline $0.5-0.599$ & $4(6.66)$ & $3(5)$ & - \\
\hline $0.6-0.699$ & $1(1.67)$ & - & - \\
\hline $0.7-0.799$ & $5(8.33)$ & $2(3.33)$ & $1(1.67)$ \\
\hline $0.8-0.899$ & $11(18.33)$ & $8(13.34)$ & $5(8.3)$ \\
\hline
\end{tabular}




\section{Analysis of Output and Input Slacks}

Table 6 gives the summary of output and input slacks under CRS specification for fish farmers in the study area.

Output slacks represent the amount by which farmers could increase production without necessarily increasing the level of input, while input slacks indicate the amount by which farmers could reduce input use without reducing the level of output, with existing technology. The result shows that there are opportunities for some of the farms to reduce their resources without reducing their output. Fish output displayed a mean slack of $0.08 \mathrm{~kg}$ in one farm. Pond size shows a mean slack of $49.535 \mathrm{~m}^{2}$ among 11 farms, 11 farms used an excess feed of $40.183 \mathrm{~kg}, 4$ farms stocked 38 fingerlings in excess, while 11 farms spent an excess of 1868.66. This inefficient spending and over use of resources may be due to inadequate knowledge of appropriate production practices and non-reliance on prescriptions of extension agents.

Table 6. Input Slacks and number of farms using Excess inputs

\begin{tabular}{|l|l|l|l|l|}
\hline Output/Input use & Number of farms & Mean slack & Mean Input use & Excess input use \\
\hline Fish $(\mathrm{kg})$ & 1 & 0.080 & 1549.07 & 4.184 \\
\hline Pond size $\left(\mathrm{m}^{2}\right)$ & 11 & 49.535 & 302.902 & 2972.091 \\
\hline Feed $(\mathrm{kg})$ & 11 & 40.183 & 428.76 & 2411.008 \\
\hline Fingerling (no) & 4 & 38.038 & 2402.56 & 2284.597 \\
\hline Labour ( $\mathrm{N})$ & 11 & 1868.658 & 48311.67 & 112119.49 \\
\hline
\end{tabular}

\section{Source: Field survey 2014}

\section{Return to Scale Properties}

Table 7 depicts the characteristics of optimal, sub-optimal and super optimal fish farms. Optimal farms are farms with constant return to scale, sub-optimal are farms with increasing return to scale while super optimal are farms with decreasing return to scale. Table 24 indicates that majority $(56.7 \%)$ of the fish farms operate under sub-optimal condition, Optimal fish farmers had the highest yield per $\mathrm{m}^{2}$ of about $2652.17 \mathrm{~kg}$ with least pond size of $172.25 \mathrm{~m}^{2}$

Table 7. Characteristics of farms with respect to return to scale

\begin{tabular}{|l|l|l|l|l|l|}
\hline Variable & No of farms & Percentage $(\%)$ & Yield $(\mathrm{kg})$ & Pond size $\left(\mathrm{m}^{2}\right)$ & Gross margin \\
\hline Sub optima & 34 & 56.7 & 836.82 & 217.52 & 182128.1 \\
\hline Optima & 15 & 25.0 & 2652.47 & 172.25 & 766728.3 \\
\hline Super optima & 11 & 18.3 & 2245.91 & 744.96 & 493645.5 \\
\hline
\end{tabular}

Source: Field survey 2011

\section{Output Target}

Table 8 gives the summary of output target. The output target refers to the amount of output, the decision making unit should aim at producing, given the available unit of inputs. The minimum output target that some of the DMU should aim at producing fell within the range of 1-500 kilograms. Only about $33.4 \%$ of the total DMU in the study is applicable. The maximum output target range is 5000kilograms and above.

Table 8. Frequency distribution of output target

\begin{tabular}{|l|l|l|}
\hline Target output & Frequency & Percentage (\%) \\
\hline $1-500$ & 20 & 33.4 \\
\hline $501-1000$ & 4 & 6.7 \\
\hline $1001-1500$ & 9 & 15.0 \\
\hline $1501-2000$ & 8 & 13.0 \\
\hline $2001-2500$ & 7 & 11.7 \\
\hline $2501-3000$ & 6 & 10.0 \\
\hline $3001-3500$ & 1 & 1.7 \\
\hline $3501-4000$ & 2 & 3.4 \\
\hline $4001-4500$ & 1 & 1.7 \\
\hline $4501-5000$ & 1 & 1.7 \\
\hline Above 5000 & 1 & 1.7 \\
\hline Total & 60 & 100 \\
\hline
\end{tabular}

Source: Field survey 2014 


\section{Major Constraints of Fish Farming in Study Area}

Table 9 indicate the case of multiple responses of fish farmers. It reveals that $76.7 \%$ of the respondents agreed that there was limited credit, $31.7 \%$ of the respondents agreed that quality feed is a problem, $48.3 \%$ agreed there is marketing problem, while $50 \%$ of the respondents agreed signified there is problem of transportation. From the response given by fish farmers in Ido and Oluyole local government, it should be deduced that financial and transport problems are the major problem. The policy implication of this is that production would be low since farmers had no enough capital to start, also transportation cost would increase their cost of production. This would reduce their output at the end of production.

Table 9. Distribution of farmers according to the constraints faced

\begin{tabular}{|l|l|l|}
\hline Constraints & Frequency & Percentage (\%) \\
\hline Limited credit & 46 & 76.7 \\
\hline Quality feed & 19 & 31.7 \\
\hline Marketing & 31 & 51.7 \\
\hline Transport & 30 & 50 \\
\hline & & \\
\hline
\end{tabular}

Source: Field survey 2014.

Multiple Responses

\section{CONCLUSION}

From the study, it can be concluded that there exist more potential that remained untapped in fish production, in the study areas. There is scope for increasing fish production efficiency by about $15 \%$, $11 \%, 5 \%$ for technical efficiency under CRS, VRS and Scale efficiency specification respectively. The determinants of efficiency are farmers' sex, age, fish farming experience and access to credit. The result of cost and return analysis shows that fish enterprise is profitable with a gross margin of \$385389.66 and a benefit-cost ratio of 2.4. It is also concluded that access to credit constitute major constraint, followed by transportation, quality feed (probably due to high cost) and marketing.

\section{REFERENCES}

Adewuyi, S.A., B.B. Philip, I.A. Ayinde and D. Akerele(2010). "Analysis of Profitability of Fish Farming in Ogun State, Nigeria”. Journal of Human Ecology, 31(3): 179-184.

Anonymous 2001: Key Figures from the Norwegian Aquaculture Industry, 2000. Directorate of Fisheries, Department of Aquaculture Bergen, Norway.15 pages.

Ajao, A.O.(2011). "Comparative technical efficiency of concrete and earthen pond in Oyo state, Nigeria" .Global journal frontier research, 11(9).10 pages.

Balogun, A.M. and Fasakin, E.A. (1995). "Flesh yield and aspect of chemical composition of commercial important fresh water species". Journal of agric technology, 4(1): 33-41.

Barnhizer, D. (2001): "Trade, Environment and Human Rights: The Paradigm Case of Industrial.

Aquaculture and the Exploitation of Traditional Communities". In D. Barnhizer, ed. Effective Strategies for Protecting for Protecting Human Rights: Economic Sanctions, Use of National Courts and International Flora, and Coercive Power". Asghate, Burlington Vermont.

Davies,R.M; O.A.Davies, M.B.Inko-Tariah and D.O.Bekibele(2008)."The Mechanisation of Fish Farms in Rivers state, Nigeria”.World Applied Sciences Journal 3(6): 926-929.

World fish centre (2003). Fish an issue for everyone : A concept paper for fish for all summit.P.10

Debtanu Barman and Sagar C. Mandal (2011): "Achieving Self Sufficiency in Fish Production in Tripura State of India-some Policies and Suggestions".

Dr. rer.nalMaraBoer, Herman OHO-Lubker (2010): "Indoor fish farming". Publication of Big Dutchman International Gmblt, 2010 edition.

Ekunwe, P.A., and C.O Emakoro (2009): "Technical Efficiency of Cat Fish Farmers in Kaduna, Nigeria". Journal of Applied Sciences Research 5(7): 8.

Fapohunda, O.O. (2005): "Profitability of Homestead Fish Farming in Ondo State, Nigeria". Journal of Annual and Vertinary Advances, 4(6): 598-602. 
Folke, C., N. Kautsky and M. Troell (1994): "The Costs of Eutrophication from Salmon Farming: Implications Policy". Journal of Environmental Management 40: 173-182.

Food and Agricultural Organization (FAO) (2000): "Fishery Production Statistics". FAO (2002).Food and Agricultural Publication, Year Report 2002.FAO Rome, pp.1-6.

Gabriel, U.U., Akinrotimi, O.A., Bekibele D.O., Anyawu, P.E. and Onukwu D.N. (2007): "Economic Benefit and Ecological Efficiency of Integrated Fish Farming in Nigeria". Academic Journal of Scientific Research and Essay, 2(8): 302.

Gowen, R.J. and N.B. Bradbury (1987): The Ecological Impact of Salmoid Farming in Coastal Waters; A Review of Oceanography and Marine, Biology Annual Review 25: 563-575.

Ibid, Smash \&Grab: Conflict, Corruption and Human Rights Abuses in the Shrimp Farming Industry, 2003. Environmental Justice Foundation. London, United Kingdom.

Inioni, O.E. (2007): "Allocative Efficiency in Pond Fish in Delta State, Nigeria: A Production Function Approach". Journal of Agriculture Tropical et al. Subtropical, 40(4): 127-134

Kautsky, N.H. Berg, C. Folke, J. Larsson, and M. Troell (1997): Ecological Foot Prints for Assessment of Resources Use and Development Limitations in Shrimp and Tilapia Aquaculture". Aquaculture Research 28: 753-766.

Luxembourg E. (2005): "The Present State of Aquaculture in the European States Member its Future up to 2005". The Official Website for Wincosin Department of Natural Resources.

Milewski, I. (2001): "Impacts of Salmon Aquaculture on the Coastal Environment: a review. Pp 166197 in M.F. Tlusty, D. Bengsten. H. Halvorson, S. Oktay, J. Pearce, and R.B. Rheault, eds. Marine aquaculture and the environment. A Meeting for Stakeholders in the Northeast.Cape Cod Press, Falmouth, Massachusetts.

Mohammed, M.H. (1994). "Fish culture: Productivity or Profitability?"ILEIA News letter .10.1.marzo.

NAERLS (2000): "Economics of Aquaculture Production". Extension Bulletin No. 107: Fishery Series No. 5 pp3-9.

Naylor, R.L., R.J. Goldburg, J.H. primavera, N. Kaultsky, M.C.M. Beveridge, J. Clay, C. Folke, J. Lubchencho, H. Mooney, and M. Troell (2000): "Effect of Aquaculture on World Fish Supplies. Nature 405: 1017-1024.

Oguntade, A.E., OkaforChris,Mafimisebi, T.E, and Fatunmbi. T.E (2011). "Technical efficiency of cocoa farm in cross river state, Nigeria". African journal of Agricultural research, 6(22): 50805086.

Ogunniyi, L.T and Oladejo, J.A (2011). "Technical efficiency of tomato production in Oyo state, Nigeria". Agricultural science research journal 1(4): 84-89.

Olagunju, F.I., I.O. Adesiyan and A.A. Ezekiel (2007): "Economic Viability of Catfish Production in Oyo State, Nigeria”. Journal of Human Ecology, 21(2): 121-124.

Sidewell, V. (1981): "Chemical and Nutritional Composition of Fin Fishes, Wales, Crustaceans and their Products" NOAA Technical Memorandum, MMFS/SEC-11, Washington DC, USA.

Weber, M. 2003. What price farmed fish: The Environmental and Social Costs of Farming Carnivorous Fish. Report for the Sea Web Aquaculture Clearing. 